Lasījumu noslēgumā notika diskusija, kas aptvēra visas iepriekšminētās tēmas, kā arī perspektīvas un problēmjautājumus, kas ar tām saistīti. Piemēram, nozīmīgs aspekts ir nedestruktīvu analīžu (rentgenstaru difrakcija, rentgenstaru fluorescence, radiogrāfija) izmantošana keramikas trauku ornamenta un glazūras izpētē. Tāpat diskusijas laikā tika akcentēts, cik svarīgi ir izmantot vairākas analītiskās metodes keramikas izpētē, lai iegūtu pēc iespējas precīzāku rezultātu. Arī māla paraugu ievākšana un salīdzināšana ar arheolog̣iskās keramikas materiālu, izmantojot gan petrogrāfiskās, gan arī ķīmiskās analīzes, spēj sniegt lieliskus rezultātus, piemēram, par keramikas darbnīcu novietojumu, izmantoto resursu attālumu, kas ir nozīmīgs aspekts zināšanu pārneses un savstarpējo kontaktu kontekstā.

Tika akcentēti arī divi problēmjautājumi: 1) kultūras procesu skaidrošana, izmantojot tikai keramikas petrogrāfiskās analīzes regionā, kurā ir homogēna geologiskā vide, respektīvi, kā ir iespējams noteikt keramikas izgatavošanas tradīciju maiņu un kopienu podnieku veidmasas atškirīibas, izmantojot lokālos resursus, ja tie ir tādi paši visā reǵionā; 2) liesinātāju identificēšanas problemātika, respektīvi, kurā brīdī piejaukumu ir iespējams identificēt kā liesinātāju un kurā brīdī tā ir nejaušỉba (šajā gadījumā bija runa par slānekli un dzelzs savienojumiem kā iespējamajiem liesinātājiem māla masā).

2018. gada Keramikas petrologijas biedrības zinātniskie lasījumi notiks Tībingenes Universitātes Arheometrijas kompetences centrā BādenēVirtembergā (Competence Centre Archaeometry Baden-Wuerttemberg) Vācijā.

Vanda Visocka

DOI: http://doi.org/10.22364/lviz.107.07

STARPTAUTISKA KONFERENCE “VIENA
VĒSTURNIEKA TRİS DZİVES: ROBERTS VIPERS
(1859-1954) KRIEVU, LATVIEŠU UN PADOMJU
HISTORIOGRĀFIJĀ"

2018. gada 23. un 24. martā Latvijas Universitātes (LU) Bibliotēkā norisinājās konference Viena vēsturnieka trīs dzīves: Roberts Vipers (1859-1954) krievu, latviešu un padomju historiogräfijā. Robertam Viperam veltītajā konferencē 12 priekšlasijumos pētnieki no Latvijas, Krievijas un Vācijas ieskicēja vēsturnieka profesionālās un privātās gaitas trīs atškịrīgos varas režīmos, kas attiecīgi sadalījuši arī paša Vipera dzīvi trīs vis- 
notal neatkarīgos posmos. Konferences atklāšanā Vācu vēstures institūta Maskavā (Deutsches Historisches Institut Moscow) direktors profesors Dr. Nikolauss Kacers (Nikolaus Katzer) salīdzināja Vipera mūžu ar vienreizēju iespēju dzīvot gandrīz kā datorspēlē, kur, izvēloties sev vienu tēlu, var izdzīvot scenārijus trīs dažādu noteikumu, valstu un notikumu pasaulēs. Lai gan vēsturnieks daḷēji pats izvēlējās savas trīs dzìves, lielā mērā viṇu uz to nenoliedzami piespieda straujās politiskās, sociālās un ideologiskās pārmaiņas 19./20. gs. mijā un 20. gs. pirmajā pusē.

Konferenci atklāja LU Vēstures un filozofijas fakultātes dekāne asociètā profesore Valda Kḷava, kas uzsvēra šīs tikšanās nozīmi divos aspektos. Pirmkārt, Roberta Vipera personība iemieso l̦oti sarežgìitu un ideologiski piepildìtu laiku. Otrkārt, pateicoties šīs vēsturiskās personības izpētei, ir izveidojusies jauna profesionāla sadarbība ar Vācu vēstures institūtu Maskavā. V. Kḷava savu runu noslēdza ar domu, ka ir pienācis laiks uzdot aktuālus jautājumus un rast jaunas atbildes ne tikai par Roberta Vipera personību, bet arī darbu metodologiju un to ideologisko kontekstu. Turklāt to darīt, atceroties konferences galvenā varoṇa aicinājumu - vienmēr pārskatìt jau izpētītus vēstures jautājumus, atgriežoties pie to kodola. Tika sacīts paldies arī galvenajam konferences idejas autoram vai, kā tika teikts, ideju generatoram profesoram Ilgvaram Misānam, pēc kura ierosinājuma tapusi ne tikai pati konference, bet arī virtuāla izstāde. Izstādi Akadēmiķis, vēstures profesors Roberts Vipers (02.04.1859.-30.12.1954.) veidojusi LU Bibliotēkas informācijas speciāliste Irina Buša, to iespējams aplūkot LU mājaslapā. ${ }^{1}$

Konferences darbs noritēja divas dienas un bija sadalīts sešās sekcijās. Referātos tika ieskicēti Roberta Vipera personīgās dzīves pavērsieni un to ietekme uz vēsturnieka profesionālo darbību. Darba valodas bija krievu un vācu, ko zināmā mērā var minēt kā visnotal̦ ekskluzīvu niansi - konferences laikā vairākkārt tika uzsvērta šo valodu nozīmība visu trīs valstu vēstures izpētē.

\section{Pirmā diena}

\section{Pirmā sekcija}

Pirmās sekcijas priekšlasījumi tika veltīti laikmeta ietekmei uz Roberta Vipera personības veidošanos.

Profesors Dr. Jans Kusbers (Jan Kusber) no Maincas Universitātes atzīmēja, ka viņa pirmā saskarsme ar Vipera darbiem bijusi, lasot monogrāfiju Ivans Bargais. Tā kā minētais darbs bijis spēcīgi ideologizēts,

1 Sk.: https://www.biblioteka.lu.lv/izstades/virtualas-izstades/roberts-vipers/ 
referentu šis pētījums nav uzrunājis, un nākamā iepazīšanās ar Vipera vārdu un darbiem notika tikai pēc sadarbības uzsākšanas ar LU un profesoru Ilgvaru Misānu. Kusberu īpaši ieinteresēja Roberta Vipera pedagogiskā darbība. Referents uzsvēra arī Vipera sievas lomu akadēmiķa izaugsmē - tieši viņa bija galvenā padomdevēja un atbalstītāja. Pēc viṇa domām, pētot Vipera darbus un personību, būtu jāpatur prātā vairākas lietas - Vipers bija savam laikam revolucionāri domājoša personība, kas ar saviem publicistikas darbiem un lekcijām spēja aizraut ikvienu. Pozitīvi vai negatīvi vērtēts, bet par viņu turpināja runāt. Gan Krievijā, gan Latvijā viņš savus studentus aicināja skatīties ne tikai vietējo historiogrāfiju, bet iepazīties arī ar Francijā un Anglijā izdotiem darbiem, kas ne vienmēr patika citiem mācībspēkiem un pastāvošajai varai. Vipers bija universālvēsturnieks, kas spēja atrast unikālo jebkurā periodā, bet nespecializējās vienā konkrētā jautājumā. Tomēr galvenokārt jāpievērš uzmanība tam, vai Vipera darbu nav ietekmējuši personīgās dzīves notikumi un otrādi. Galu galā jāatceras paša Vipera izteiktā tēze: Vēsture jāraksta, kāda tā ir, nevis tāda, kā vajag.

Klātesošajos īpašu interesi izraisīja Krievijas kolēges Dr. Antoṇinas Šarovas (Antonina Sharova) ziņojums par Roberta Vipera kā vēsturnieka fenomenu. Referāta sagatavošanā izmantoti līdz šim neapzināti Maskavas Universitātes personu lietu dokumenti, kuri glabājas dažādos Krievijas vēstures arhīvos, piemēram, Vipera vēstule Staḷinam. Galvenais jautājums, ko izvirzīja referente, - kā bija iespējams, ka Vipers, kurš aizbrauca no Krievijas 20. gados kā bezpartejisks, L̦eņina kritizēts vēsturnieks, tad 17 gadus uzturējās buržuāziskā Latvijā un rakstīja pētījumus atbilstoši politiskajai iekārtai, vēlāk spēja atgriezties PSRS galvaspilsētā? Maskavā viņa darbus lasīja un atzina gan Stąlins, gan daudzi komunistiskie līderi. Vai iemesls bija tas, ka daudzi studenti, kuri bija mācījušies pie Vipera Maskavas Universitātē, 40. gados ieņēma augstus amatus sociālistiskajā nomenklatūrā? Viṇa darbi intelektuālajā sabiedrības slānī padomju varas laikā nebūt nebija zuduši. Lai arī domas raisījās un viedokḷi bija dažādi, viennozīmīgu atbildi uz izvirzìtajiem jautājumiem konferences dalībniekiem neizdevās rast.

\section{Otrā sekcija}

Pētnieks Detlefs Henings (Detlef Henning) no Hamburgas Universitātes vērsa klausītāju uzmanību uz vēstures zinātni starpkaru periodā un Roberta Vipera lomu tajā. Viena no galvenajām izvirzītajām atziņām brīdī, kad Vipers pievienojās Latvijas vēsturnieku elitei, pēkšņi mainījās līdzšinējā viendimensionālā vācbaltiešu historiogrāfija. Lai gan mūsdienās jau zināmā mērā novecojusi, monogrāfija Lielās vēstures problēmas 
tomēr savā laikā bija pirmais vēstures teorijas - filozofijas darbs, kas kā pionieris arī ir palicis vienīgais līdz mūsdienām. Roberts Vipers bija pirmais, kas mēgeināja arī Latvijas vēsturi no lokālas padarīt par globālu, uzsverot, ka nav iespējams pilnībā nodalīt kādas vienas valsts vēsturi, turklāt tā vienmēr ir jāpēta kontekstā ar citu valstu un reǵiona norisēm. Pēc viṇa domām, Otrā pasaules kara priekšvakarā vēstures izpētei bija atkal jāmainās, jo Latvija vairs nebija perifērija, bet robežšķirtne, kur satikās divas lielvaras.

Dr. Maike Zaha (Maike Sach) no Maincas Universitātes savā referātā pievērsās jautājumam par Roberta Vipera gatavotajiem materiāliem Latvijas Universitātē lasītajam Latvijas vēstures lekciju kursam. Tie glabājas Latvijas Universitātes Akadēmiskajā bibliotēkā un līdz šim nav publicēti vai tulkoti. Referente informēja, ka nākamgad kursa materiāli tiks pilnībā pārtulkoti un publicēti vācu valodā ar zinātniskiem komentāriem. Viņa ieskicēja arī būtiskākās šo lekcijas kursu atziṇas - tiek konsekventi turpināta ideja par vēstures pētniecību, iekḷaujot izpētāmās tēmas kopīgā kontekstā, neatraujot tās no kopējiem, globāliem notikumiem. Vipers pirmais pievērsa uzmanību laika posmam, kad Baltijas valstīs ienāca kristīgā ticība, salīdzinot ar tās attīstības cel̦u citās Eiropas valstīs. Materiāli ir gana interesanti un vērtīgi gan no historiogrāfijas, gan metodologijas viedokḷa. Caur šo lekciju kursu Vipers saviem studentiem modelēja globālu skatījumu uz viduslaiku vēsturi un aicināja atteikties no lineāras vienvirziena pieejas, kas atrauti iztirzātu kādu vienu Latvijas nacionālās vēstures tēmu.

Pēc otrās sekcijas noslēguma referenti devās uz Latvijas Universitātes Akadēmisko bibliotēku, kur galvenās bibliotekāres Aijas Taimiņas pavadībā bija iespēja klātienē ieraudzīt materiālus, ar kuriem Vipers strādāja, veicot savus pētījumus par Latvijas vēsturi. Tika dota iespēja aplūkot arī paša Vipera, laikabiedru un studentu rokrakstus un fotogrāfijas.

\section{Otrā diena}

\section{Trešā sekcija}

Otrās dienas darbu konferencē aizsāka pašmāju referenti no LU Vēstures un filozofijas fakultātes.

Profesors Dr. Gvido Straube referātā vērsa uzmanību uz to, ka, lai arī Roberts Vipers ar savu darbību uzsāka jaunas diskusijas par dažādiem vēstures jautājumiem, lielākā daḷa viṇa laika vēsturnieku un sabiedrības tomēr nepiekrita šiem pētījumiem, jo tie noliedza vairākas līdz tam iesakņojušās vēsturiskās patiesības. Vipers pirmais un līdz šim arī vienīgais analizēja bruṇinieku tiesības salīdzinājumā ar citviet izdotām līdzīgām 
tiesībām, kā, piemēram, Sachsenspiegel. ${ }^{2}$ Viņa pētījumos var redzēt - nav neviena pavediena, kas apliecinātu cīṇu starp bruṇniecību un zemniekiem. Tieši pretēji, 14./15. gadsimtā valda savstarpējs atbalsts, kas arī atbilst tā laika iespējai izdzīvot un pragmatiski pastāvēt līdzās. Citāda situācija veidojās tikai vēlāk - 16. gs. beigās, kad augstmaṇu gimenes arvien vairāk ierobežoja zemnieku tiesības un tas noveda pie Rozena deklarācijas. Šie Vipera apgalvojumi, protams, nepatika vietējai vācbaltiešu vēsturnieku pārstāvniecībai. Taču tie nepatika arī latviešu izcelsmes vēsturniekiem, jo būtībā noliedza 700 gadu verdzības teoriju. Vipers nonāca krustugunīs, jo runāja par lietām, kas viṇa laika vēstures zinātnē bija izskaidrotas jau 19. gadsimtā.

Asociētā profesore Valda Kḷava sava referāta tēmu bija izvēlējusies saistīt ar Roberta Vipera darbu Jauno laiku vēsture četros sējumos, kas ieņem l̦oti nozīmīgu lomu 20. gs. 30. gadu historiogrāfijā. Tajā Vipers pauda ideju, ka renesanse nav atmoda, bet gan drīzāk sabiedrības pagrimšana, jo tieši šajā laikā sākās arvien lielāka tās noslāṇošanās. Viṇš neuzskatìja arī, ka reformācija pēc savām iezīmēm pieder pie jauno laiku vēstures posma, bet drīzāk vēl pie viduslaikiem. Viens no uzkrītošākajiem akcentiem, kas saskatāms Vipera darbos, ir personību lielā loma. Pēc referentes domām, to izvērtējums gan ir ḷoti subjektīvs, un šķiet, ka Vipers dažām lietām (piemēram, vai vēsturiskais personāžs bijis precējusies, kā juties psiholog̣iski u.tml.) piešķīris pārāk lielu lomu.

\section{Ceturtā sekcija}

Profesors Dr. Ilgvars Misāns savā referātā pievērsās jau pieminētajai Vipera monogrāfijai Lielās vēstures problēmas un analizēja Viperu kā Latvijas vēsturnieku. Vēlreiz tika uzsvērts, ka Roberts Vipers savā laikā Latvijā pieskārās līdz tam pētījumos neapskatītiem jautājumiem, lai gan ar Latvijas vēsturi līdz pārcelšanās brīdim nebija pazīstams. Vipers aicināja atzīt zemnieku lomu vēstures attīstībā, kas saskanēja ar latviešu vēsturniekiem, taču tajā pašā laikā uzsvari un akcenti viņa pētījumos atš̌kīās. Vipera salīdzinošā metode attīstīja vietējās vēstures izpēti. Monogrāfijā Lielās vēstures problēmas viņš pievērsās tādiem vēstures zinātnes jautājumiem, uz kuriem ir grūti rast atbildi arī mūsdienās. Teksts šobrīd ir novecojis, tomēr liela daļa no Vipera uzdotajiem un aprakstītajiem problēmjautājumiem vēl arvien ir aktuāli. Šì referāta laikā izvērsās arī diskusija, kuras ietvaros vairāki pašreizējie un bijušie vēstures studenti izteicās par aplūkoto Vipera darbu.

2 Saksijas spogulis - 13. gs. likumu krājums, kas bijis pamatā daudziem citiem likumkrājumiem, to skaitā Magdeburgas pilsētas tiesībām, kas ietekmējušas arī Latvijas teritorijā veidotus likumus. 
Jāatzīmē, ka atšḳirīgas paaudzes šo darbu studiju procesā traktējušas ḷoti dažādi. Diskusijas noslēguma secinājums gan vēsta, ka Vipera Lielās vēstures problēmas būtībā vēl aizvien ir l̦oti nozīmīgs darbs, bet noderētu dzil̦āka gan pašas monogrāfijas, gan Vipera personības analīze.

Maskavas Augstākās ekonomikas skolas Humanitāro zinātņu fakultātes docente Natālija Almazova (Natal'ia Almazova) pieskārās Roberta Vipera darbiem par antīko vēsturi un centās analizēt ideju par to, vai viṇš ir pielīdzināms vācu vēsturniekam Eduardam Meijeram. Lai gan referāta tēma vērtējama kā daudzsološa, autores izvēlētie akcenti stāstījumā būtiskas atziṇas par pētāmo tēmu neatklāja.

\section{Piektā sekcija}

Maskavas Valsts universitātes pētnieks Dr. Dmitrijs Volodihins (Dmitrii Volodikhin) raksturoja Robertu Viperu kā liberāli domājošu cilvēku, kurš mīlēja Krievijas valsti, cienīja un atbalstīja indivīda izaugsmi. Iespējams, tieši šì iemesla dẹl viņš personībām pieškīra tik lielu lomu vēstures notikumu attīstībā. Referātā tika aplūkots viens no populārākajiem Vipera darbiem, kas 1944. gadā, kad grāmata tika izdota atkārtoti, piedzīvoja būtiskas pārmaiṇas, jo vairs neatbilda ideologiskajai nostādnei, proti, pētijums par Ivanu IV Bargo. Darbs ir mulsinošs, jo padomju izdevumā valdnieks pēkšn,i ir zaudējis jebkādas bardzības pazīmes. Ir izṇemtas lietas, kas varētu traucēt tā brīža valdības ideolog̣ijas pamatam. Darba pirmizdevums ir skaists un filozofiski dziḷ̌š, bet 1944. gadā iznākušais, ar kuru pazīstama lielākā daḷa sabiedrības, ir politisks izdevums. Oriǵinālu Vipers rakstīja gluži kā eksperimentu, izmantojot daudzo gadu gaitā izstrādātās un izkoptās pētniecības metodes. Viṇš neuzskatīja, ka vēstures attīstībā nepieciešams progress un ka tās attīstības mērḳis ir progress. Viṇaprāt, viss notiek aplveida kustībā, kurā saskatāmi kāpumi un kritumi. Tà, piemēram, cilvēces attīstībā kolektivizācija nenoliedzami ir kritiens, jo kultūras attīstībai nepieciešama brīvība un individuāla attīstība.

Krievijas Zinātṇu akadēmijas Sabiedrisko zinātṇu informācijas institūta sektora vadītājs Aleksandrs Gordons (Aleksandr Gordon) klātesošos aicināja atcerēties, cik svarīgi ir neaizmirst Krievijas vēstures hronologiskos posmus jeb, citējot pašu referāta autoru: Par kuru Krieviju mēs runājam? Brīdī, kad Roberts Vipers atgriezās Krievijā pēc 17 gadu prombūtnes, valsts jau bija transformējusies. Jau kopš 1936. gada to var saukt par pārterorizējušos. Lai legiitimētu notiekošo teroru, bija nepieciešami atzīti autori. Pie varas bija jaunā vecā patiesība. Vēsturnieka galvenais uzdevums bija parādīt piederību un tā mācīt patriotismu. Tikmēr tās galvenais uzdevums tuvināt vēstures pētniecību, lai tā būtu patiesāka un ne tik daudz vērsta uz vienas tautas izcelšanu pāri citām, tika aizmirsts. 


\section{Sestā sekcija}

Maincas Universitātē strādājošā Latvijas pētniece Dr. Svetlana Bogojavḷenska savā ziṇojumā pievērsās vēl kādai jau pieminētai Roberta Vipera dzīves kaislíbai - pedagoga darbam un viņa prasmei veidot mācību līdzekḷus. 1924. gadā pēc ierašanās Latvijā Viperu rosināja veidot jaunas mācību grāmatas mazākumtautību skolām. Vēlāk izrādījās, ka Vipera valoda un izteiktās tēzes ir pārāk sarežgìtas 3. un 4. klases skolēniem, tāpēc viṇa rakstîto pievienoja 5. un 6. klases mācību materiāliem. Bet arī tad škita, ka Vipera grāmata netiek izmantota kā pamatmācību līdzeklis - vai nu sarežgìitības dẹl, vai tādēl, ka Vipers arī skolu grāmatās mēgināja izlīdzināt valstu nozīmīgumu, piešķirot katrai attiecīgu lomu un skatoties uz Eiropu kopumā. No politiskā viedokḷa tas neatbilda mazākumtautîbu skolu politikai, jo pēc vadlīnijām mācīblīdzekḷi bija jāveido tā, lai, piemēram, bērns, kurš audzis ārpus Krievijas, kādu dienu būtu spējīgs arì kulturālā un vēstures zināšanu līmenī atgriezties dzimtenē. Referente atzīmēja, ka nav atradusi pašu 1928. gadā izdoto Vipera mācību grāmatu pamatskolai, tikai skopus aprakstus par to, kas savukārt neḷauj izdarīt pilnvērtīgus secinājumus par Vipera veidoto mācību līdzekli.

LU Filozofijas un sociologijas institūta vadošā pētniece Dr. phil. Svetlana Kovaḷčuka savu ziṇojumu iesāka aizrautīgi ar šādiem vārdiem: 1941. gada 16. maijā 16.35 aizgāja vilciens Rīga-Maskava. Mums ir precīzi zināms laiks un datums, kad studentu mīlotais pasniedzējs Roberts Vipers devās atpakal uz dzimteni, bet precizzas ziņas par ierašanos Latvijā vēl arvien trūkst. Tālāk referātā tika aplūkota vēsturnieka ierašanās un gaitas Latvijā. 1922. gada 23. augustā Vipers Maskavas Universitātē izteica vēlmi lasìt lekcijas Latvijas Universitātē, tomēr atbrauca tikai divus gadus vēlāk. Līdz šim vēl aizvien nav skaidrs, kāds bijis kavēšanās iemesls, jo, spriežot pēc dokumentiem, nekādi šķērṣ̦̌i ne no Maskavas Universitātes, ne valdības puses netika likti. Referāta autore, līdzīgi kā pirmās dienas referente Antoṇina Šarova, vērsa uzmanību uz to, ka nereti gan Viperu dzīves laikā, gan mūsdienās tiek jaukti tēvs un dēls. Kovaḷčuka atklāja vairākas vēsturnieka personīgās iezīmes, kuras saskatāmas arī viṇa pētījumos. Kā ḷoti būtisku iezīmi var minēt Vipera uzskatu, ka patiesību var izzināt, vien pievēršoties vēstures saknēm un oriğinālam. Tuklāt ir jāuzdod atkārtoti jautājumi atšķirīgos vēstures posmos. Abu Viperu - Roberta un Borisa lekcijas bijušas studentu iemīlotas un labi apmeklētas. To apstiprina saglabājušās atmiṇas, kas apskatāmas Akadēmiskajā bibliotēkā. Fragmentā, ar kuru tika dota iespēja iepazīties klātienē, uzsvērts, ka citās lekcijās vēl tā, bet pie Vipera lekcijās bija jāierodas laikus, citādi nebija kur sēdēt. Viperu dzīvoklis atradies tuvu Universitātei, tādēl lekcijas lasītas arī svētdienās. 
Roberta Vipera personība un profesionālā darbība bijusi tikpat raiba kā politiskie notikumi viņa dzīves laikā. Kas ir bijuši tie faktori, kas ietekmējuši Roberta Vipera personīgo dzīi un profesionālo darbību? Kāda loma bijusi viṇa darbiem historiogrāfijā? Cik nozīmīga loma vēsturnieka darbiem bija toreiz un tagad? Šos un citus jautājumus uzdeva referenti un konferences dalībnieki divu dienu garumā. Protams, ne vienmēr var rast simtprocentīgu atbildi, un, iespējams, tas nemaz nav nepieciešams. Domājams, ka konferences galvenais varonis par šādām diskusijām būtu bijis priecīgs, jo viens no galvenajiem Vipera uzstādījumiem vēsta, ka nedrīkst vēsturi atstāt tādu, kāda tā kaut kad uzrakstīta - tā atkal un atkal jāatklāj no jauna, papildinot ar jaunu informāciju un metodēm, meklējot kodolu un izejas punktu. Latvijas historiogrāfijā trūkst zinātnisku pētījumu par to vēsturnieku biogrāfijām, kas bijuši paḳ̣auti politiskajām pārmaiṇām. Ikviens vēstures pētniecībai piesaistītais ir kādā brīdī saskāries ar Roberta Vipera vārdu vai vismaz viņa metodologisko monogrāfiju Vēstures lielās problēmas. Šì darba un tā autora vērtējumi ir dažādi, bet varbūt tieši tāds ir bijis Roberta Vipera vēstīiums nākotnes pētniekiem - rast atbildes uz nezināmo, meklēt atbildes baltajiem plankumiem, tādā veidā veidojot plastisku, kontekstā balstītu vēsturi. Gaidīsim šìs konferences materializēšanos rakstu krājumā!

Liene Rokpelne

\section{LATVIJAS VĒSTURNIEKU II KONGRESS. 2018. GADA 18.-19. JŪNIJS}

Latvijas vēsturnieku I kongress veiksmīgi aizritēja 2011. gadā, un tā rīkotāji un dalībnieki vēlējās aizsākt jaunu tradīciju Latvijas vēsturnieku dzīvē - rīkot šādu vēsturnieku kopā sanākšanu reizi piecos gados. Tomēr dažādu iemeslu dēḷ 2016. gadā kongresu rīkot neviens neuzṇēmās, pie vainas daḷejji esot finansējuma jautājumam un varbūt daḷeji arī tādēḷ, ka ìsti nebija skaidrs, kuram būtu jābūt atbildīgam par vēsturnieku kongresu tradīcijas turpināšanu. Tuvojoties Latvijas simtgadei un vienlaikus jau septītajam gadam kopš pirmā kongresa, arvien vairāk kḷuva skaidrs, ka, ja otro kongresu neizdotos sarīkot Latvijas jubilejas gadā, tad Latvijas vēsturnieku kongresu tradīcija var arī izbeigties, lāga neiesākusies.

Piesardzīgi izteikto domu par otro Latvijas vēsturnieku kongresu ar entuziasmu uzṇēma Latvijas Republikas Izglìtības un zinātnes ministrija (IZM). IZM, piesaistot šim mērḳim finansējumu no Eiropas Regionālās 